УДК 330.15:504.06

() 2014

Самойлік М. С., кандидат економічних наук

Полтавський національний технічний університет ім. Юрія Кондратюка

\title{
МЕТОДОЛОГІЧНІ ЗАСАДИ ЗАБЕЗПЕЧЕННЯ РЕСУРСНО-ЕКОЛОГІЧНОЇ БЕЗПЕКИ У РЕГІОНІ
}

\section{Рецензент - доктор економічних наук, професор В. В. Писаренко}

Розроблені методологічні засади забезпечення ресурсно-екологічної безпеки регіону, щцо включають три етапи: ідентифікацію небезпеки, визначення зон ресурсно-екологічної безпеки та формування ідеї вирімення проблеми; вибір заходів забезпечення достатнього рівня ресурсно-екологічної безпеки регіону на основі оптимізаційних економічних моделей та комплексної оцінки альтернативних сценаріїв використання природно-економічного потенціалу регіону, щзо враховує екологічний, економічний та технологічний критерії; коректування та узгодження рішень на основі інтегральної моделі розвитку економікоекологічних систем використання вторинних матеріальних та енертетичних ресурсів регіону з урахуванням внутрішньорегіональної специфіки.

Ключові слова: ресурсно-екологічна безпека, регіон, вторинні ресурси, тверді відходи.

Постановка проблеми. Проблема досягнення сталого розвитку регіону розширює сферу впливу людини на навколишнє середовище й інтенсифікує використання природно-сировинної бази, що неминуче ставить проблему раціонального використання вторинних ресурсів на перший план. Основними джерелами вторинних ресурсів служать відходи виробничої та споживчої діяльності людини. Проблема раціонального використання вторинних ресурсів є однією 3 пріоритетних для кожного регіону України [1]. У такому аспекті підвищення ефективності використання природно-економічного потенціалу території, у тому числі й на основі капіталізації відходів виробництва і споживання, стає одним із пріоритетних завдань регіонального розвитку.

Аналіз останніх досліджень і публікацій, у яких започатковано розв'язання проблеми. Значний внесок у розробку теоретичних і методологічних засад збалансованого соціальноекономічного розвитку регіонів зробили Б. Буркинський, В. Волошин, 3. Герасимчук, Б. Данилишин, С. Дорогунцов, Д. Медоуз, В. Онищенко, В. Трегобчук та інші науковці. Фундаментальним дослідженням взаємодії суспільства і природи присвячені праці В. Вернадського, О. Клименка, Л. Купінець, Л. Мельника, Ю. Одума, С. Подолінського, Н. Реймерса, М. Руденка, Дж. Форес- тера та ін. Водночас залишаються відкритими для наукового пошуку питання стосовно формування нових підходів до забезпечення ресурсноекологічної безпеки регіонів, підвищення ефективності управління вторинними ресурсами, що базуються на розробці інноваційної методології розвитку соціально-економічної системи, визначенні економічних моделей і механізмів підтримання прийняття управлінських рішень із використанням методології системного аналізу з урахуванням екологічних, технологічних і соціально-економічних умов функціонування такої системи на регіональному рівні.

Мета дослідження: розробити й науково обгрунтувати науково-методичні засади забезпечення ресурсно-екологічної безпеки регіонів України, орієнтованих на підвищення ефективності використання природно-економічного потенціалу території, ресурсозбереження й ресурсозаміщення на основі капіталізації твердих відходів (ТВ) і мінімізації їх негативного впливу.

Результати дослідженнея. Ресурсно-екологічної безпека регіону - це стан регіональної природно-соціально-економічної системи, що забезпечує запобігання погіршення якості екосистем та здоров'я людини в разі поліпшення соціально-економічного стану даної системи (мінімум ентропіі), з урахуванням впливу дестабілізуючих ресурсних та екологічних загроз зовнішнього і внутрішнього середовищ, через механізм підвищення ефективності використання природно-економічного потенціалу території, орієнтованого на ресурсозбереження та ресурсозаміщення, у тому числі на основі капіталізації відходів виробництва і споживання як вторинних ресурсів, а також мінімізації негативного впливу відходів на якість первинних ресурсів. Особливе місце в цьому повинно відводитися розгляду відходів як специфічного товару, який необхідно залучати в повторний обіг у максимальній кількості, що дозволить: поліпшити ресурсозабезпеченість i конкурентоспроможність регіону, отримати додатковий дохід від вторресурсів, зберегти первинні ресурси, покращивши їх якість, повернути забруднені землі у господар- 
ський обіг регіону (відображає економічний та ресурсний аспект); зменшити ризик здоров'ю населення від негативного впливу відходів, покращити соціально-психологічний клімат у регіоні (відображає соціальний аспект); забезпечити збереження і відновлення навколишнього середовища регіону, природного стану екосистем та мінімуму ентропії (відображає екологічний аспект).

Комплексний підхід до забезпечення ресурсно-екологічної безпеки регіону має включати наступні складові:

- ідентифікацію небезпеки та визначення зон ресурсно-екологічної безпеки, на основі чого формується теоретико-методичний підхід до вибору стратегій забезпечення достатнього рівня ресурсно-екологічної безпеки;

- науково-методичні засади вибору заходів забезпечення достатнього рівня економічної безпеки на основі оптимізаційних економічних моделей;

- коректування й узгодження рішень на основі інтегральної моделі розвитку економіко-екологічних систем використання природно-економічного потенціалу регіону (рис. 1).

На першому етапі, виходячи 3 теорії безпеки екосистем та враховуючи вплив на них соціаль- но-економічних чинників [3], розроблено теоретико-методологічний підхід щодо оцінки рівня ресурсно-екологічної безпеки регіонів у системі сталого розвитку, який полягає в розрахунку трикомпонентного показника, що враховує рівень екологічної безпеки економіки регіону (Р), рівень екологічного ризику здоров'ю населення (M) та рівень ресурсозбереження і ресурсовідновлення у регіоні (W):

$\mathrm{K}=\mathrm{f}(\mathrm{P}, \mathrm{M}, \mathrm{W})$,

$\mathrm{P}, \mathrm{M}, \mathrm{W} \rightarrow 1$, якщо $\mathrm{P}, \mathrm{S}, \mathrm{W} \geq \mathrm{P}_{\text {дост }}, \mathrm{S}_{\text {дост }}, \mathrm{W}_{\text {дост }}$;

$\mathrm{P}, \mathrm{M}, \mathrm{W} \rightarrow 0$, якщо $\mathrm{P}, \mathrm{S}, \mathrm{W}<\mathrm{P}_{\text {дост }}, \mathrm{S}_{\text {дос }} \mathrm{T}, \mathrm{W}_{\text {дост }}$,

де $\mathrm{P}_{\text {дост }}, \mathrm{M}_{\text {дсст }}, \mathrm{W}_{\text {дост }}$ - достатне значення показників $\mathrm{P}, \mathrm{M}, \mathrm{W}$.

Складові трикомпонентного показника щодо рівня ресурсно-екологічної безпеки регіону пропонується визначати так:

1) Показник екологічної безпеки економіки регіону розраховується як сумарний економічний збиток за забруднення навколишнього середовища від техногенного навантаження у регіоні за авторською методикою [5], результати розрахунку якого дали змогу визначити першочергову стратегію в напрямі удосконалення системи екологічно безпечного розвитку регіонів України (див. табл.).

Типологізація регіонів України в напрямі удосконалення системи екологічно безпечного розвитку регіонів України*

\begin{tabular}{|c|c|c|c|}
\hline \multicolumn{2}{|c|}{ Тип } & Регіони & Першочергова стратегія \\
\hline \multirow{6}{*}{ Тип A } & $\mathrm{A}_{1}$ & $\begin{array}{c}\text { Івано-Франківська, Київська, Вінницька } \\
\text { області }\end{array}$ & $\begin{array}{c}\text { Ефективна стратегія охорони } \\
\text { атмосферного повітря }\end{array}$ \\
\hline & $\mathrm{A}_{2}$ & $\begin{array}{c}\text { АР Крим, Львівська, Миколаївська, } \\
\text { Одеська, Херсонська, Черкаська області, } \\
\text { м. Київ та м. Севастополь }\end{array}$ & $\begin{array}{c}\text { Ефективна стратегія охорони водних } \\
\text { ресурсів }\end{array}$ \\
\hline & $\mathrm{A}_{3}$ & $\begin{array}{l}\text { Житомирська, Полтавська, Рівенська, } \\
\text { Сумська, Волинська області }\end{array}$ & Ефективна стратегія охорони грунтів \\
\hline & $\mathrm{A}_{1} \mathrm{~A}_{2}$ & $\begin{array}{c}\text { Дніпропетровська, Донецька, Запорізька, } \\
\text { Луганська області }\end{array}$ & $\begin{array}{l}\text { Ефективна стратегія охорони } \\
\text { атмосфери та водних ресурсів }\end{array}$ \\
\hline & $\mathrm{A}_{2} \mathrm{~A}_{3}$ & Чернігівська & $\begin{array}{c}\text { Ефективна стратегія охорони водних } \\
\text { ресурсів і грунтів }\end{array}$ \\
\hline & $\mathrm{A}_{1} \mathrm{~A}_{2} \mathrm{~A}_{3}$ & Харківська & $\begin{array}{c}\text { Ефективна стратегія охорони атмос- } \\
\text { ферного повітря, водних ресурсів } \\
\text { та грунтів }\end{array}$ \\
\hline \multicolumn{2}{|c|}{ Тип В } & $\begin{array}{c}\text { Закарпатська, Тернопільська, Хмельниць- } \\
\text { ка, Чернівецька, Кіровоградська області }\end{array}$ & $\begin{array}{c}\text { Ефективна стратегія покращання } \\
\text { системи охорони здоров'я }\end{array}$ \\
\hline
\end{tabular}

* - авторська розробка. 

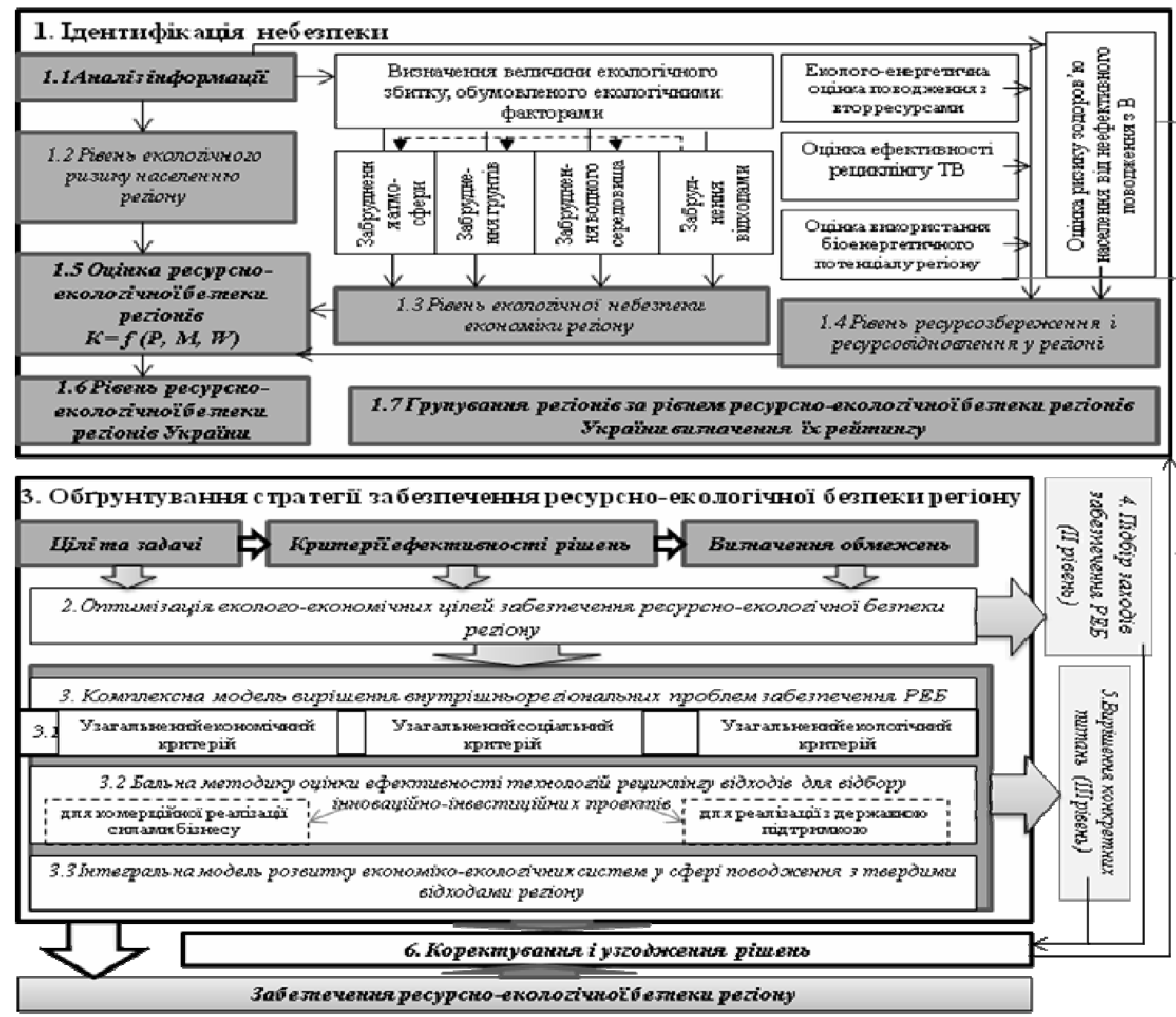

2. Фор муувамяя ідея вмрішеккя лро блем

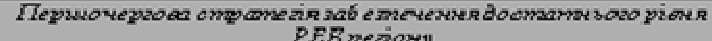

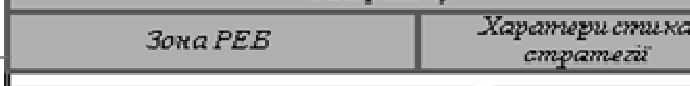

Зона абсовкатна" PED реziоку.

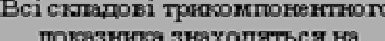
показнака знатоднте н на

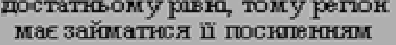

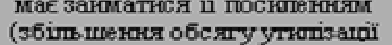

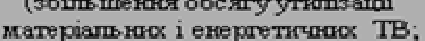

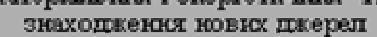
эабезпеченги ресурсноі безпетки;

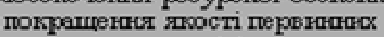
ресурсів)

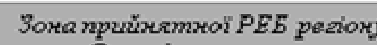
Оден is складове

трКкомпоне Ктного показник теребувае на недостатььому

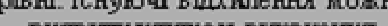
Bon

Зона химкой $P E \bar{B}$ peziony. Piвень економічюої

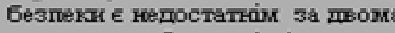

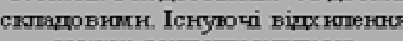

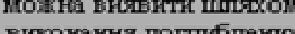
вигонання поглићления 20.

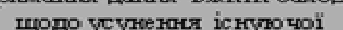

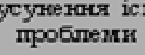

Зона неприпустимої $P E$ peziory. Pisers PEБ $e$ кедостатам одразу за трьома

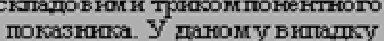
регіон мaе першичергово вирішгурати пттанек

забезпе чения екслогіi безпеки.

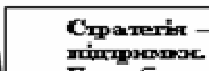

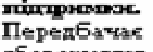
оетатьеото ріния PEБ, воктролт за реаультатылт

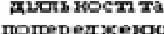

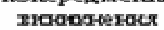
мооклихтек затроз

\section{Cpareria -} пеоведбанақ затодіг поститени: offroro is
oxpogir mocruter oдmoro 13
movasrais

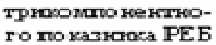
To похазнгаa FE periosy, zhawe
oworoe. недостатнік.

\section{Стратегія -}

amanrauni Здійсненгя етратегї по karpastry удоскокапек екстеми

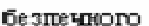
posermy (Tra A-

$$
\text { B). }
$$

Cтр атегік miin Hередбачая урозв итку
peгioну.

1. Методологічні засади забезпечення ресурсно-екологічної безпеки у регіоні (розроблено автором) 


\section{ЕКОНОМІКА}

2) Оцінку ризику здоров'ю населення можливо здійснювати за допомогою авторської моделі, що відображає різні взаємозалежності в системі відносин «людина - середовище» й наведена у [6], результати кластернізації регіонів України за даним показником приведені на рисунку 2.

3) Показник рівня ресурсозбереження та ресурсовідновлення у регіоні розраховано за авто- рською методикою [8] і включає наступні складові: енергоємність сфери поводження 3 відходами у регіоні; економічна ефективність використання вторинних ресурсів у регіоні; економічна ефективність використання біоенергетичного потенціалу у регіоні; оцінка ризику здоров'я населення від існуючої системи поводження 3 твердими відходами.

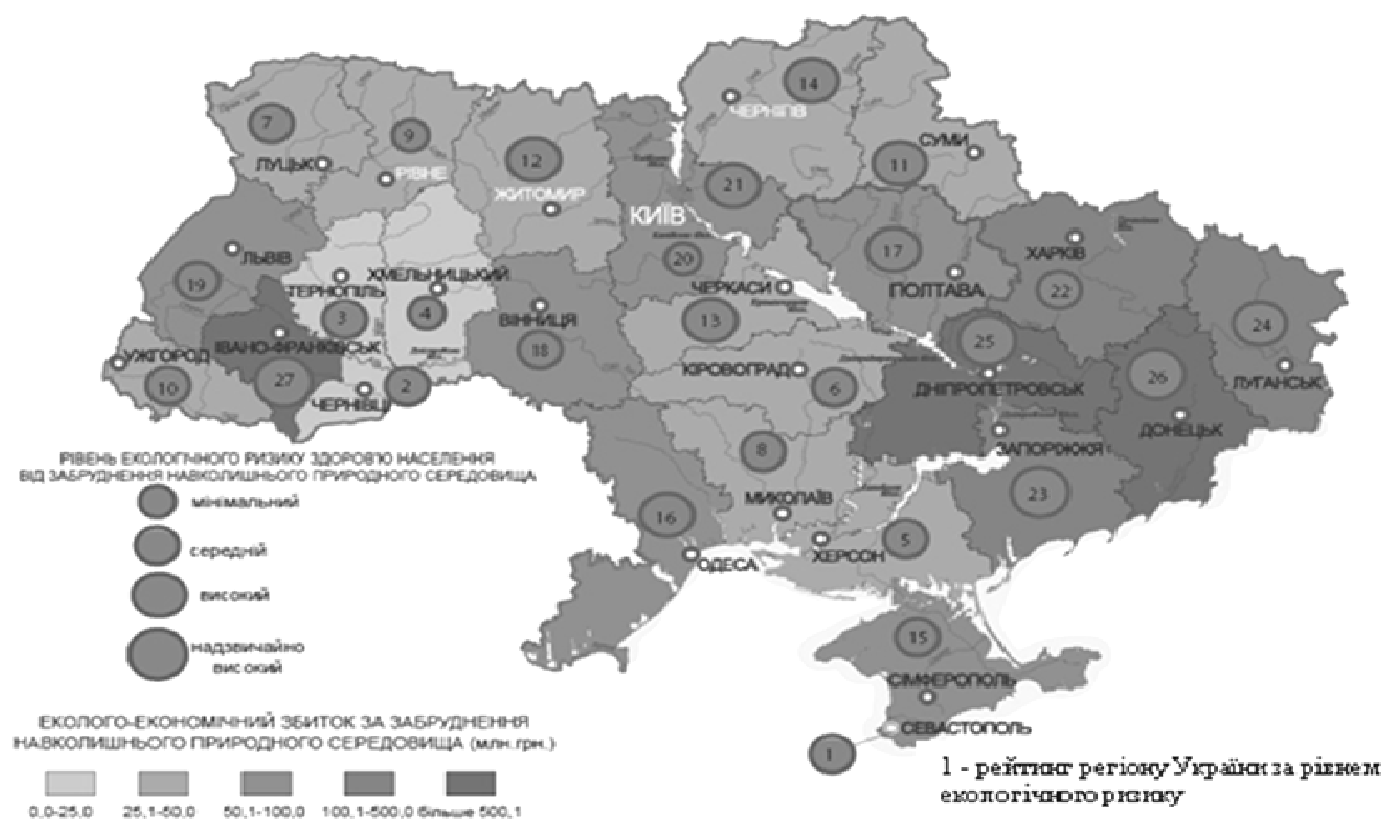

Рис. 2. Оцінка екологічного ризику за регіонами Украӥни; узагальнені дані за 2005-2012 рр. (складено автором)

\begin{tabular}{|c|c|c|c|c|c|c|}
\hline & \multicolumn{5}{|c|}{ 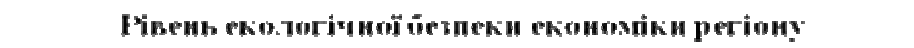 } & \\
\hline & & \multicolumn{2}{|c|}{ 2lus Iilluit } & \multicolumn{2}{|c|}{ He;т4 Janni } & \\
\hline & & \multirow{2}{*}{\multicolumn{2}{|c|}{ 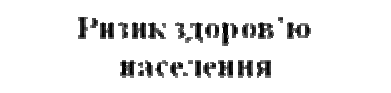 }} & \multirow{2}{*}{\multicolumn{2}{|c|}{ 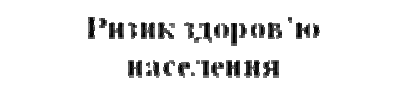 }} & \\
\hline & & & & & & Зона абісототноі \\
\hline & & 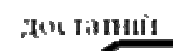 & 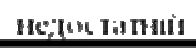 & ILแ Iatmil & 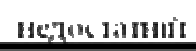 & besmera periory \\
\hline \multirow{3}{*}{ 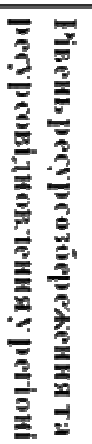 } & 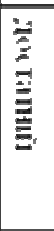 & $(1 ; 1 ; 1)$ & $(1 ; 1 ; 0)$ & $(1 ; 0 ; 1)$ & $(1 ; 0 ; 0)$ & $\begin{array}{l}\text { Зона прийнитноі } \\
\text { ресурсно-екалогіныі } \\
\text { безпека регіону }\end{array}$ \\
\hline & \multirow{2}{*}{ 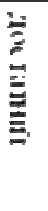 } & \multirow{2}{*}{$(0 ; 1 ; 1)$} & \multirow{2}{*}{$(0 ; 1 ; 0)$} & \multirow{2}{*}{$(0 ; 0 ; 1)$} & \multirow{2}{*}{$(0 ; 0 ; 0)$} & 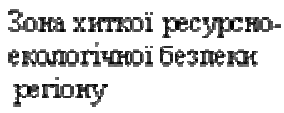 \\
\hline & & & & & & 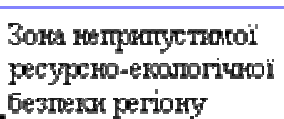 \\
\hline
\end{tabular}

Рис. 3. Зони ресурсно-екологічної безпеки регіону (складено автором) 


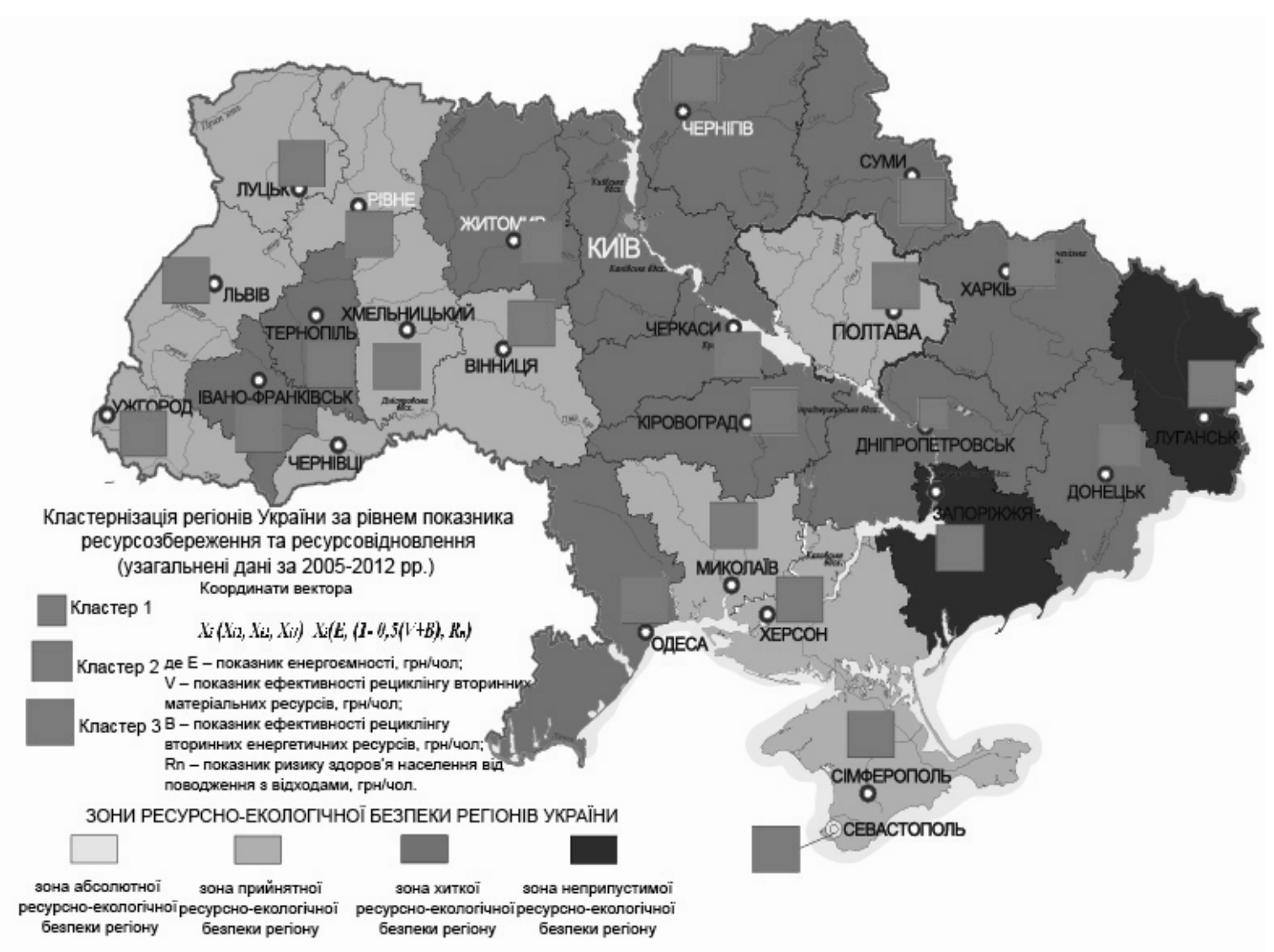

\section{Рис. 4. Типологізація регіонів Украӥни за рівнем ресурсно-екологічної безпеки;} узагальнені дані за 2005-2012 рр. (складено автором)

Теоретично можливі 8 значень трикомпонентного показника оцінки рівня ресурсноекологічної безпеки регіону К, які відповідають чотирьом зонам ресурсно-екологічної безпеки регіону (рис. 3).

Приведене дослідження вище наведених показників дало можливість визначити зони ресурс- но-екологічної безпеки регіонів України (рис. 4). Для кожної 3 виділених зон ресурсноекологічної безпеки запропоновано оптимальні стратегії забезпечення ресурсно-екологічної безпеки регіону, характеристики яких подано на рисунку 1.

\begin{tabular}{|c|c|c|c|}
\hline 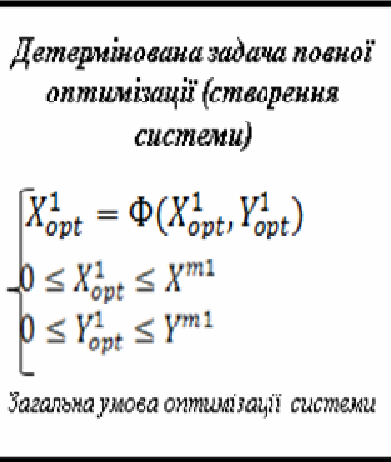 & 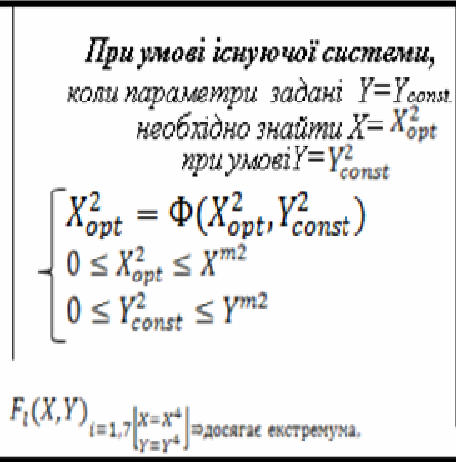 & 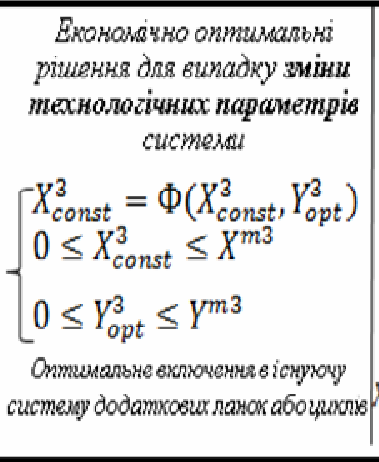 & 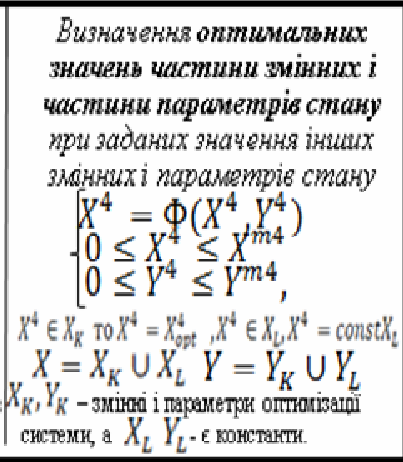 \\
\hline
\end{tabular}

Рис. 5. Задачі оптимізації розвитку сфери поводження з вторинними ресурсами регіону (складено автором) 


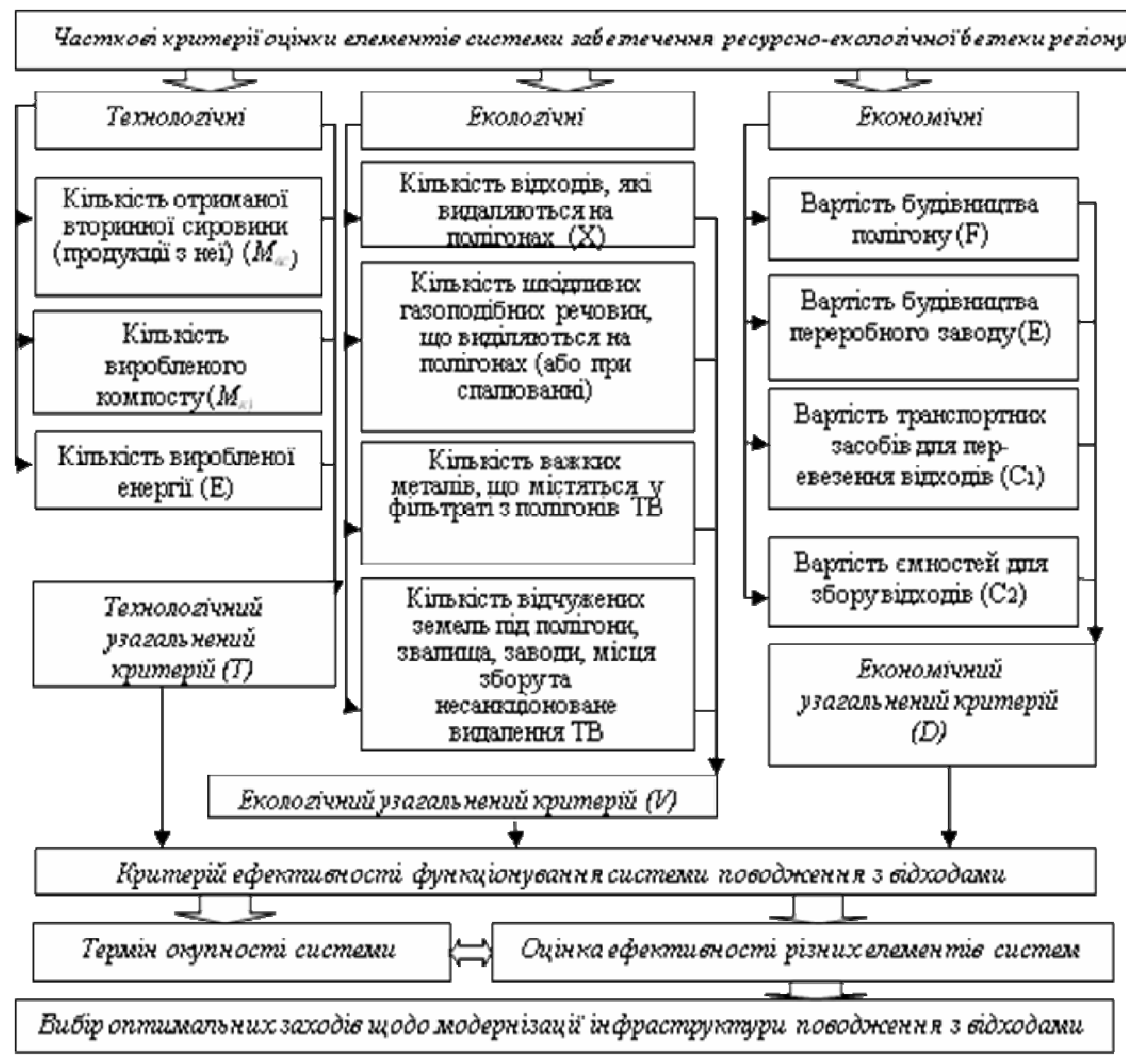

Рис. 6. Комплексна модель ефективності розвитку сфери поводження з ТВ з урахуванням регіональної специфіки (складено автором)

На другому етапі у рамках кожної стратегії визначається група заходів, на основі імітаційних економічних моделей $[2,7]$, впровадження яких може бути комплексним або пріоритетним, виходячи із фінансових можливостей регіону:

$\mathrm{X}=\Phi(\mathrm{X}, \mathrm{Y})$, при умові $\mathrm{X} \leq \mathrm{Xm}, \mathrm{Y} \leq \mathrm{Ym}$,

де: $X=X^{s} \cup X^{s} \cup \ldots \cup X^{F s} \cup \ldots \cup X^{I s}-$ множина змінних стану системи поводження з ТВ у регіоні; $Y-\left\{\alpha_{s}, \beta_{p}, \ldots, \tau^{T}\right\}$ - множина параметрів стану даної системи у регіоні; Xm, Ym - множина обмежень на змінні і параметри стану даної системи у регіоні; $Ф$ - лінійний функціонал, який пов' язує значення змінних стану між собою при заданих параметрах стану системи (рис. 5).

Так як множина $\mathrm{X}$ ширша ніж множина зв'язків у функціоналі $\Phi$, то дана система має множину допустимих рішень i, відповідно, пропонує вибір найкращого 3 них. Задача вибору найкращого рішення системи й є задачею управління системи поводження 3 ТВ, і вирішується вона за допомогою цільових функцій: мінімізації утворення відходів; мінімізації сумарних екологічних ризиків; максимального вилучення вторресурсів; максимального отримання прибутку від реалізації вторсировини; мінімізації сумарних витрат, у тому числі транспортних; максимізації прибутку для регіону.

Слід враховувати, що системи поводження 3 TB, які базуються на вирішенні часткових проблем відходоутворюючих підприємств і окремих населених міст, не дивлячись на їх високу затратність, як правило, не ефективні.

Спорудження локальних об'єктів утилізації 


\section{EKOHOMIKA}

ТВ у кожному місті, селищі або на кожному підприємстві призводить до розпорошення коштів, необгрунтованого зростання витрат на захоронення відходів і не дає можливості ефективно вирішувати проблему поводження з відходами у масштабах регіону. Виходом із ситуації, що склалася, є розробка та реалізація регіональних комплексних систем поводження 3 відходами. Тому залежно від рівня територіальнолокалізованих утворень розроблено методичні підходи до комплексної оцінки ефективності розвитку сфери поводження 3 твердими відходами 3 урахуванням регіональної інфраструктури, яка враховує екологічний, економічний і технічний критерії даної сфери й дає можливість у випадку існуючої ситуації та наявних коштів підібрати комплекс оптимальних рішень i, навпаки, переслідуючи завдання покращити стан даної сфери до певного рівня, визначити необхідні для цього ресурси у регіоні (рис. 6).

На третьому етапі забезпечення ресурсноекологічної безпеки регіону здійснюється коректування й узгодження рішень на основі інтегральної моделі розвитку економіко-екологічних систем використання природно-економічного потенціалу регіону [8], що враховує вплив ризиків на стан соціально-економічних систем і характеристику внутрішньорегіональної специфіки:

$$
\Pi=\sum_{t=a}^{T}\left[\left(\theta_{t}+U_{t}-3_{s t}\right)\left(1-\gamma_{\mathrm{nt}}\right)\left(1-\delta_{\mathrm{yst}}\right)-3_{\mathrm{wt}}-\mathrm{H}_{3 t}-\mathrm{H}_{z}-\mathbf{E}_{R t}-E_{\mathrm{ut} t} \mathrm{~K} \pm \Delta \mathrm{B}_{\mathrm{spt}}\right](1+E)^{-t} \rightarrow \max (3)
$$

де: $\boldsymbol{Z}$ - прибуток, який лишається у розпорядженні об'єкта, який працює у сфері поводження з ТВ, грн; $\theta_{t}-$ плата за приймання відходів, грн; $3_{s}$ - щорічні витрати виробництва, що віднесені до собівартості, грн; $\gamma_{H-}$ функція, що враховує систему державних, регіональних і місцевих податків; $\delta_{y \iota}-$ функція, що враховує умови участі засновників та інвесторів у розподілі прибутку; $3_{м}$ - матеріальні й інші витрати, що не включаються в собівартість, грн; $\mathrm{H}_{3}$ - вартість земель, що виводяться з сільськогосподарського обігу, грн; $\mathrm{H}_{\varepsilon}-$ сумарні додаткові платежі, що включають плату за кредит, плату за понадлімітне забруднення довкілля тощо, грн; $\mathrm{E}_{R}-$ екологічний ризик, виражений у грошовій формі, грн; $\mathrm{E}_{\text {Ин }}$ коефіцієнт ефективності капітальних вкладень у варіанті, що розглядається.

Висновок. У статті розроблені методологічні засади забезпечення ресурсно-екологічної безпеки регіону, що включають три етапи:

- ідентифікацію небезпеки та визначення зон ресурсно-екологічної безпеки, що дає можливість вибрати першочергову стратегію забезпечення ресурсно-екологічної безпеки регіону;

- вибір заходів забезпечення достатнього рівня ресурсно-екологічної безпеки регіону на основі оптимізаційних економічних моделей та комплексної оцінки альтернативних сценаріїв, що враховує екологічний, економічний та технологічний критерії;

- коректування й узгодження рішень на основі інтегральної моделі розвитку економіко-еколо-

\section{БІБЛІОГРАФІЯ}

1. Онищенко В. О. Регіональна програма охорони довкілля, раціонального використання природних ресурсів та забезпечення екологічної безпеки з урахуванням регіональних пріоритетів Полтавської області / В. О. Онищенко, Ю. С. Голік, О. Е. Ілляш [та ін.]. - Полтава : Полтавський літератор, 2012. - 164 с.

2. Онищенко В. О. Теоретико-методологічні засади управління сферою поводження 3 твердими відходами на регіональному рівні: монографія / В. О. Онищенко, М. С. Самойлік. - Полтава : ПолтНТУ, 2013. - 524 с. гічних систем використання природно-економічного потенціалу регіону з урахуванням внутрішньорегіональної специфіки.

До того ж реалізація запланованих стратегій i заходів дасть змогу: піднести ресурсозабезпеченість і конкурентоспроможність регіону, отримати додатковий дохід від вторресурсів, зберегти первинні ресурси й поліпшити їх якість, повернути забруднені землі у господарський обіг регіону; зменшити ризик здоров'ю населення від негативного впливу відходів, поліпшити соціально-психологічний клімат у регіоні; забезпечити збереження і відновлення довкілля регіону, природного стану екосистем.

3. Реймерс Н. Ф. Природопользование / Н. Ф. Реймерс. - М. : Мысль, 1990. - 424 с.

4. Самойлік M. С. Еколого-економічна оцінка забруднення навколишнього середовища в системі екологічно безпечного розвитку регіонів України: монографія / М. С. Самойлік, С. В. Онищенко. - Полтава : ПолтНТУ, 2012. - 269 с.

5. Самойлік М. С. Оцінка ризику здоров'ю населення при використанні різних технологічних рішень у сфері поводження 3 твердими відходами на регіональному рівні / М. С. Самойлік // Таврійський науковий вісник. - Вип. 82. - 


\section{ЕКОНОМІКА}

Херсон : Грінь, 2013. - С. 350-356.

6. Самойлік М. С. Екологічне обгрунтування соціально-економічного розвитку сільських територій за рахунок утворення екопоселень / М. С. Самойлік // Вісник ПДАА. - 2013. - №4. C. 10-14.

7. Самойлік M. C. Оптимізаційна модель управління системою поводження з твердими відходами регіону / М. С. Самойлік // Матеріали міжна- родної науково-практичної конференції «Соціально-економічні аспекти реструктуризації регіональної економіки - 2014» (6-7 лютого 2014 року, м. Вінниця).

8. Onyschenko V. O. Strategic management directions of solid domestic waste sphere in the Poltava region / V. O. Onyschenko. M. S. Samojlik // Економіка і регіон. - 2013. - №3. - C. 3-8. 